\title{
THE LEGAL NATURE OF PUBLIC CONTROL
}

\section{Zhanna Kovalenko ${ }^{1}$ Taras Gurzhiy ${ }^{2}$}

DOI: https://doi.org/10.30525/978-9934-588-15-0-82

Abstract. At present day public control is not just a compulsory element of civil society and a vivid manifestation of the constitutional thesis that the only source of power in Ukraine is the people, but it is also a form of feedback between the society and the state. Taking into consideration the way that this channel of interaction/communication is established, dependence lies not only on the field of political capacity of citizens, but also upon the degree of legitimacy of public authority. On the other hand, the legitimacy of the government directly influences the quickness and efficiency of reforming for all major spheres of society life, bringing national legislation into common line with the legislation of the European Union, successful completion of the European integration process and, as the consequence, Ukraine's establishment as European modern country. The functioning of public control requires existent proper legal, organizational and institutional framework based on the acts of national law. However, taking into consideration that neither in practice nor in theory a single conceptual approach to the definition of the legal nature of public control has yet been developed; so, the main purpose of the article is to determine the legal nature of the latter and to disclose modern understanding of this legal phenomenon. In order to achieve it, the author has analyzed the main approaches to understanding of the "legal nature" concept, revealed the main criteria for determining legitimate nature of public control, distinguished public control from the concepts of "civic control", "social control", "commonalty control", "communal control" and "general control"; along with it the relation between the concepts of "public control" and of "the participation in management of state affairs"

\footnotetext{
${ }^{1}$ Assistant-consultant to People's Deputy of Ukraine, Verkhovna Rada of Ukraine; Postgraduate Student,

Kyiv National University of Trade and Economics, Ukraine

${ }^{2}$ Doctor of Law, Professor,

Head of the Department of Administrative, Financial and Information Law,

Kyiv National University of Trade and Economics, Ukraine
}

(C) Zhanna Kovalenko, Taras Gurzhiy 
has been revealed. The methodological basis of the research is represented through general scientific and special methods, in particular: dialectical, structural-logical, systemic, logical-semantic, methods of classification and grouping, comparative-legal method and method of scientific abstraction. These methods have been applied in conjunction with common logical methods and techniques (analysis, synthesis, induction, deduction, analogy). In conclusions the authors give their own vision of the concept of "legal nature of public control" and propose to understand public control under one of the forms of executing the right to participate in public administration, which ensures the organization and implementation of state power in the direction of the fulfilment of tasks, functions and innovations, assigned to it by the Law, as well as the achievement of its main goal - to provide and ensure human rights and freedoms, and decent living conditions. It seems that the conducted research is not just to show up significant influence as for the development of "normal science", but also to gain certain theoretical basis for determining the way of legal regulation of social relations in the sphere of functioning of public control. The research seemingly manifests and contributes further improvement of the mechanisms for interaction between state and society.

\section{Introduction}

The quickness and efficiency of all major spheres of society lifetime reforming, the adaptation of national legislation to the legislation of the European Union depends on many factors. Among the latter the definitive place occupies the legitimacy of public authority, which can be provided, in particular, through the feedback establishment between society and state. One of forms for such a communication is the public control, which is not only necessary element of civil society, but also clear manifestation of the constitutional thesis that the only source of power in Ukraine is its people.

The functioning of public control requires existent appropriate legal, organizational and institutional basis, grounded on acts of the national Law. However, there is still no single conceptual approach to determining of the legal nature of this legal phenomenon, both on the level of practitioners and at the level of theory. At first glance, the solution to this common problem depends not only on the development of "normal science", but also upon determining ways to regulate social relations in the sphere of public control. It seems obvious that this will improve the mechanisms of interaction 
between the state and the community and increase the level of legitimacy of public authority.

The purpose of the article is to determine legal nature of public control and to uncover modern understanding of this legal phenomenon. To achieve this authors analyze: 1) main approaches to understanding the concept of "legal nature"; 2) the disclosure of basic criteria for determining the legal nature of any legal phenomenon in general and public control in particular; 2) differentiation of public control from related concepts; 3 ) the correlation between the notions "public control" and "participation in the management of state affairs".

The methodological basis of the research is general scientific and special methods, namely: dialectical, structural-logical, systemic, logical-semantic, methods of classification and grouping, comparative-legal method and method of scientific abstraction. These methods were applied in conjunction with the common logical methods and techniques (analysis, synthesis, induction, deduction, analogy).

\section{Scientific approach to the legal nature comprehension}

Contemporary understanding of the concept "legal nature" is one of the most commonly used in juridical discourse. It is being used nowadays both in historical-legitimate and sectoral legal studies. This is due to the fact that every legal phenomenon is characterized by legal nature without exception.

The widespread use of the concept of "legal nature" and, at first quick glance, its unambiguous understanding is by no means being the basis for asserting the accuracy and uniformity of approaches to its usage. Today, the preferences of the majority of authors do not reveal the essence of this concept, as a result of which the problems of legal nature have not yet received proper theoretical understanding and appropriate elaboration.

At the same time, we should agree with the E.G. Komisarova's idea that "the definition of the legal nature allows not just to represent legal characterization of a juridical phenomenon, to understand its place and role among others, but also to reveal prerequisite condition, which mandatory affects its legal characteristics"[1, p. 27].

In order to fully and accurate disclosure of the legal nature for public control, we believe that it is essential to explore the basic approaches to understanding the concept of legal nature. 
Thus, one of the first to attempt giving the definition of the legal nature concept is the theorist of law S.S. Alekseyev. In his opinion, the legal nature should be considered as the juridical nature and it is to be defined through jurisdictional characteristics of this legal phenomenon, which characterize its structure and reflect its place and role among other legal phenomena in accordance with its social nature [2]. To our mind, this seems somewhat contradictory. After all, the scholar reviews the legal nature as a derivative phenomenon from the social nature which primarily provides social filling of the norms of law. At the same time, the researcher equates the right to the law, thereby offsetting the value of the previous thesis.

Speaking about the complex nature of issues under study as for the legal accident, we cannot fail to mention the Russian scientist I.V. Matveyev. According to his idea, the legal nature of the phenomenon is the essence of the phenomenon, which is determined by its characteristic features [3,p. 11]. While giving due credit to the author for constructing a clear definition of the concept of "legal nature", it should be noted that this attempt was not quite successful, because the characterization of the basic category of "the nature" through the category of essence has very little contributed to the disclosure of its content. The fact is that both of these categories are often used interchangeably in the scientific and dictionary literature $[4 ; 5 ; 6]$. Taking this into consideration, we may confirm that the substitution of one term for another (a similar one) in no way helps the reader to penetrate more deeply into the essence of the analyzed phenomenon. The same thing concerns the part of I.V. Matveyev's definition, which refers to "defining the legal nature of a phenomenon by its characterization". Since the essence of any phenomenon is revealed by its characteristic, such a feature cannot be recognized as informative and at least a bit useful in terms of scientific comprehension.

More profound attempt to discover the essence of the legal nature was made by E.G. Komisarova. Thus, according to her idea, at first it is necessary to establish the essence of the concept "nature". On the other hand, on the basis of G. Hegel idea analysis we may conclude that determining the essence of this phenomenon it is necessary to identify its foundation [1, p. 25].

In our opinion, the researcher's statement under consideration is somewhat debatable, since the concept of "nature" has the status of a category, as well as wide "geography" of applications and a range of understandings, but the legal nature is intrinsic to purely legal phenomena only; so its consideration 
separately from the word "legal" does not allow to reveal the meaning of this concept accurately.

Unveiling the essence of the legal nature concept, E.G. Komisarova turns to the worked-out results in the framework of philosophy again, in particular analyzing the views of prominent representatives of German philosophy and philosophers of the Middle Ages. Thus, having examined Eriugenus, E.G. Komisarova states that speaking of the nature of this phenomenon, first of all, we're bearing in mind its primal, leading, and its starting point as it is, which caused the original existence of the phenomenon itself, its essence and entity.

The definition of legal nature through the concept of "the primal", "the leading", "the beginning", "the essence", "the entity", "the foundation", in our opinion, is somewhat false, because it does not just bring to clarity, but vice versa becomes more confusing. In addition, according to the requirements relating to terms, the latter should be used in one meaning only, that is in the sense in which they are commonly used [7].

By the way, it is not hardly to be noticed that the scientist studies some works of philosophers mainly. However, in our opinion, the analysis of the question under study from the standpoint of general philosophy and yet separate from the juridical science is neither true nor expedient. Well, the legal nature is the subject of study for exclusively juridical science and then the philosophy of law after all.

As a result, E.G. Komisarova emphasizes that it is possible to move to comprehension of the legal nature through cognition of functions, definition of legal character, clarification of the limits for scientific application, which in no way negates its mutual relationship with terms like "legal evaluation "(qualification), “ legal characteristics", "legal regime", "function", as well as with the method of legal regulation [1, p. 26-27].

The mentioned-above author's summary conclusion is unlikely to bring any clarity to the definition of the core essence of this concept, but rather deprives it of the status for possessing particular concept, its own specificity and semantic load.

However, revisiting the works of domestic scientists, so they unfortunately did not dedicate their research to the question of legal nature as it is. Considering it as a self-explanatory clear phenomenon, they considered it only in the context of developing other scientific problems, 
often limited only to fixing it in the title of the work. It was clear only from the text what would legal nature mean.

However, in the field of domestic legal science there are still scholars who deal with issues of legal nature, albeit indirectly. Among them, A.S. Pavlenko deserves special attention.

Thus, exploring the legal nature, the scientist makes an intermediate statement, according to which, legal nature is both the juridical essence and the phenomenon of legal entity. Similarly, in our opinion, the meaning is primarily devoid of the sense, because the essence and the phenomenon are not identical concepts.

Despite the fallacy of the primary scientist's judgments on the investigation, during the process of research A.S. Pavlenko was the first to try defining the concept of legal nature, outlining its main characteristic features, among which: 1) legal nature manifests itself within the norm of law, and in various principally and regulatory means; 2) legal nature arises at the moment of law cognition in the process of different types of legal activity; 3 ) the legal nature contains the meaning of legal prescription established by the norms of law; 4) legal nature is a set of essential features of legal objects of cognition; 5) the legal nature allows not just to understand the artificially created legal order, but also to determine social relations that are subject to legal putting it into order [8, p. 78].

According to the proposed definition by this author, legal nature is a system of unchanging essential characteristic features of a juridical object, which are manifested in the process of its cognition and allow to determine the meaning of the legal phenomenon, as well as to establish the belonging of legal fact to the hypothesis of the norm of law or some other object related with law, corresponding legal category [8, p. 79].

It goes without saying that the proposed definition has the right for living on, but it is important to determine its validity and quality. For this purpose, in our opinion, it is worth analyzing the key essential feature that the scientist has suggested, namely: the legal nature arises at the moment of law cognition in the process of different types of legal activity. Yes, indeed, law enforcement practice involves normative legal assessment of a particular fact and the establishment of an appropriate norm of law. However, such activities are not aimed to determine the legal nature of certain legal phenomena, since its main task is the proper application of the positive 
law. Also in this case, the successful is the opinion of E.S. Kubriakova; she states that the ambiguous term "nature" (and, accordingly, "legal nature") is capable to generate (and is generating) different understanding of it, but in any sense the legal nature cannot arise "in the moment of law cognition in the process of different types of legal activity", because it arises at the moment of occurrence of the phenomenon (in condition that it has the one) and exists regardless of whether one knows it in the process of any kind of legal activity or does not cognize it at all [9, p. 197].

Of course, the attempt of A.S. Pavlenko to define the concept of legal nature, some characteristic features of its essence is of great importance for legal science. However, the features proposed by the author "blur" the meaning of this concept, which leads to considerable loss of its scientific value.

\section{Criteria for determining the legal nature of public control}

The legal nature is a reflection of nature of the law itself. In its turn, the nature of law is the subject of the philosophy of law, which is the doctrine of the marginal foundations of law [10]. However, the latter in no way dictates the need for methodological step beyond the limits of legal science. In this case it is necessary to proceed from the generally accepted approaches of law theorists onto the nature of law.

In this regard being successful, to our mind, is the classification of forms of law proposed by Professor S.I. Maximov, to which he attributed: 1) the world of ideas (the idea of law); 2) the world of sign forms (legal rules and laws); 3) the world of social interactions (legal life) [11]. The validity of his views is obvious, because in 10 years similar opinion was expressed by O.G. Lukyanova; that is, she believed that the highest form of the law entity was his (S. I. Maximov's) idea, which reveals its essence [12, p. 27].

Undoubtedly, in unity of these levels that the law exists as it is. However, the incipience of law in the whole (as the consequence in specific fields) appears at the forefront - on the level of ideas. Therefore, to our opinion, the most pertinent is the interpretation of the legal nature in the whole and the legal nature of public control, in particular, through the prism of the idea that underlies in its foundation being the social content of the legal regulation of relevant social relations.

At the same time, it shouldn't be tossed to the back of the mind that any idea of legitimacy must be formulated in the light of the philosophical 
conception of law, according to which the law is concerned as a set of values and normative systems that include fundamental moral principles and values based on more specific and historically transitional forms the Law (the Legislation) [13, p. 10-11].

As for the mentioned above, we consider that the key criteria for determining the legal nature of any legal phenomenon in general and public control, in particular are: 1) the idea of this legal phenomenon; 2) the valuenormative basis within which the idea of a corresponding legal phenomenon is incepted.

First of all, let us examine the value-normative system, which is a favorable "space" for the idea of public control. It should be noted that this system is the product of relevant paradigm of law, therefore the legal nature of public control is also conditioned by the paradigm of law.

In her turn, V.V. Starchikova believes that the meaning and conceptual content of public control varies, being rested on different concepts of legal constitutional state [14]. Instead, according to V. Yakushik, when considering issues of different kinds of legal state, in fact it is necessary to bear in mind that there are many models (types and varieties) of the legal state, which have been formed under specific cultural and historical conditions, and therefore may vary greatly from one another (slavery, noble, liberal, social, democratic and humanistic) [15, p. 181-185].

Taking into account that the assignment of this study is not just to disclose the genesis of the legal nature of public control, the interest is stated on the modern paradigm of law only, and accordingly, the general concept of the legal state in its modern dimension in the whole, and in Ukraine in particular.

Thus, in Ukraine since the first years of independence on the level of the Basic Law, the main principles of the legal state have been fixed, being almost like a "mirror" reflection of the concept of legal state, which is inherent from the Western civilization. The established concept of the legal state has affirmed as the product of Western civilization. However, due to the lack of standards for their implementation in practice, the corresponding model underwent some deformation.

Along with it the international legal system is characterized by modern legal concept of the legal state, the essence of which is that by its sociopolitical content the theory and practice of legal state are aimed at affirming 
the principle of sovereignty of the people, submission of the state to the society, protection of human and citizen rights and freedoms [16]. The latter hasn't been just recognized by the international community, which has also found its manifestation in a number of important international documents, including fundamental ones, such as the Universal Declaration of Human Rights, the International Pact on Civil and Political Rights, The International Pact on Economic, Social and Cultural Rights, the Convention for the Protection of Human Rights and Fundamental Freedoms.

Ratification of the above-mentioned documents has determined the course of development of our country. As a result, Ukraine has established a concept whereby the people with their rights and freedoms are regarded as the absolute value of the state. And this, in its turn, has not just given the impetus to create a favorable environment for the development of civil society in our country, but also led to the adoption of the best acquisitions of political and legal thought by Ukraine, which leading countries of the world (including EU countries with stable democracy) have been propagated and adhered to for decades.

The pro-European movement vector of our country stipulates integration of basic European values, which in our view areas follows: freedom and responsibility for it, dignity and equality of people, legal state, democracy, civil society, tolerance, justice.

The analysis of the above-mentioned allows us to assume that today there is a certain system of social values existing in the world. It is common to most countries of the world, and its elements are closely interconnected. However, in our opinion, the constituent values of public control are democracy, legal state and civil society. As a consequence, we believe that in order to determine the legal nature of the legal phenomenon under study in the whole, and its ideas in particular, it is necessary to reveal the relationship between democracy, legal state and civil society.

Considering legal state, we have to note that it is based on the principle, according to which the freedom of one person ends there, where the freedom of another one begins. That is, if one person violates the rights of another, he/she is held accountable in accordance with the rules of law that ensure the protection of the rights and freedoms of all people and citizens. The legal state presupposes the law-abiding nature of all, regardless of status and social position: everyone, that is ordinary workers, state servants, ministers, 
and even the president must be held accountable for the violations of the law. Lawfulness means that the people recognize the existing power as legal, and the existing legal norms are being that they do not violate their rights and freedoms, but on the contrary - protect them. If the government exceeds its authority and violates fundamental human rights, re-election may be possible to hold.

Speaking on democracy (most likely on parliamentary one, because it is the value of Europe) [17], we have to note on the recognition of the sovereignty and the rule of power of the people who defend their rights, interests and freedoms through the relevant representatives in power. Democratic values would require the development of parliamentarism, the establishment of institution for open universal secret elections (secret ballot). To prevent transformation of democracy into dictatorship of the majority, the restrictions were limited by dividing power into legislative, executive and judicial branches. This principle implied that neither of the branches of government could implement the powers of the other one; this very principle created the mechanisms for the independence of each branch of power, the division of powers between them, and transparent, independent judiciary. Conscious approach to the choice of power is to consider critically and rationally existing political leaders, parties, institutions, and their programs. The democracy itself empowers citizens to regain power and control over it from the side of the public.

At the same time, it should be emphasized that for all "young" democracies the most important thing is the society being developed, active and functionable one [18]. Uniting to protect and to defend the rights, interests and freedoms, people create the conditions for transition onto new quality level of the society. In the European space, these people also become citizens, because citizenship is not only a belonging to particular state, but also an active participation in public and political life. Civil society is a kind of foundation for functioning of all types of democracy. At the same time, civil society requires the creation of free, independent state associations, citizens' associations and non-governmental organizations that protect the interests of their members and participate in political life, discussing and solving social problems.

Taking into consideration the above-mentioned, it can be argued that civil society can develop within democracy only. In its turn, democracy 
prospers through a legal state in which the rule of law reigns, and the law saves and protects the rights and freedoms of all citizens effectively. Finally, it should be noted that a highly developed and really functioning civil society can be the asset of a state that is both legal and democratic.

The progressive development of any state is possible if it interacts with civil society through both dialogue and direct public participation in public administration. It is important that this interaction has to be based on the principles of equal partnership, mutual responsibility, control and restriction, because only in this case the mechanism of guaranteeing rights and freedoms of the individual and the citizen is going to be effective and efficient, which in its turn minimizes the possibility of usurpation of power.

In our opinion, the fundamental principles of activating the development of civil society are the formation of civil position, increasing social activity, overcoming social passivity, raising the level of justice, legal culture, activating the formation of effective civil society institutions and participation of citizens in public affairs management.

In its turn, the development of civil society should be directed towards establishing effective mechanisms for controlling the activity of the authorities. After all, the correction of the activities of authorities, for example, in the case of their non-compliance with the public interest, is possible only when at least the community has the right to evaluate such activities publicly.

Effective control of power is possible only within the limits of democratic constitutional state where the power is dispersed, regulated, restricted by law, being accessible, foreseeable, effective as well. Democracy being the principle of internal organization and activity of political institutions is the phenomenon of highly developed civil society [19, p. 28].

Having analyzed all of the above-stated, we believe that the idea of public control originates within democratic legal state with a developed civil society. In its turn, it should be noted that this idea is revealed as a restrictive function of society (like a restrictive function of law), which allows to provide feedback to the state for the activity of state power in accordance with and in consent with the procedure established by the law. This interpretation of the idea of the concept under study that allows to determine not only its place in the system of state-public relations, but also its meaning and role for the youth of a democratic and legal state. 


\section{Public control and related concepts}

In the legal doctrine, except public control, there often occur such categories as "civic control", "social control", "communal control", which scholars often use as identical to the researched legal phenomenon. In addition, public control is also equated with civilian control or communal control. Therefore, for a better understanding of the essence of public control (apart from defining its value-normative principles and ideas), it is necessary to separate it from the inherently similar legal phenomena.

Thus, the equation of public control with social one is based on the fact that the concept of civic development of the community is becoming more relevant today. However, when comparing these two concepts, one should derive from the idea that ideally civil society is "a society in which state and society form two clearly separated spheres, and the state has a purely instrumental nature, controlling individual interests, and in the case of necessity take into account that it is itself being under control" [20, p. 41]. As for the mentioned above, since the interaction between the state and society is not limited to control only, it is more appropriate to use the term "civic control" for this kind of form. Moreover, in terms of terminology, the term "civic" is more similar to the concept of "community".

Concerning the equation of public control with social one, and taking into account that public control is defined by a type of civic control implemented by citizens associations and directly by citizens, being an important form of citizens' constitutional rights and an active way of involving population into the activity of the state administration [21], its independence is obvious. In its turn, we note that public control and civic one correlate as common one and its part.

Drawing the line between public and civic control, the opinion of V.M. Kravchuk deserves attention, who considers as appropriate to differentiate between public and civic control, and emphasizes that the key sign of this distinction between "public control" and "civic control", collectivity and individuality, are the subjects of their implementation. That is why "public control" is realized in the forms of public councils, public examinations, public hearings, etc., and "civil control" is manifested in the forms of individual appeals of citizens, and their personal activity" [22, p. 89].

With regard to civil control, nowadays this term is also quite conditionally autonomous from public control. For example, in the New Interpretative 
Dictionary of the Ukrainian language, the word "civil" is interpreted as "secular", "civilian", "non-military", "non-clerical", etc. [4].

In addition, O.V. Poklad states that "in conditions of political modernization of Ukrainian society civil control should be considered as an institutional element of democratic political regime originated on the right of citizens to participate in public administration" [23, p. 37].

Meanwhile, S. Baranov interprets civil control as the state-independent legislative-based democratic mechanism through which civil society (its institutions) by the bodies of representative power or just directly monitors and adjusts military-force policy and practice [24, p. 52].

Therefore, civil control is endowed with virtually all the defining features of public control. However, it should be noted that this concept has its own specificity. This is linked due to the fact that in English this term is literally translated as "civilian control over the army". And now this very concept is entrenched in national military-scientific literature. Bearing this in mind, "civil control" a priori has special object of control, that is the military block of the state.

In its turn, we would like to emphasize that the term "civil control" has found its legislative expression. Firstly, in the Law of Ukraine "On Democratic Civil Control of the Military Organization and Law Enforcement Bodies of the State", and later in the Law of Ukraine "On National Security of Ukraine".

The analysis of the mentioned normative legal acts allows to confirm that the legislator considers public and civil types of control as intersecting (i. e. reciprocally imposed). Thus, in military sphere there is an element of public control (i. e. public control is an element of civil control). In its turn, civil control is one of the branches of public control (i. e. civil control is an element of public control). So, the differentiation of these types of controls depends on what is to be the primary object for the study.

Investigating the relationship between civil and public control, it should be noted that the concept of public control is firmly established in Western European legal doctrine (it is relatively new for domestic jurisprudence). Therefore, there is no surprise that the vast majority of definitions of this concept belong to foreign scholars.

In particular, American scientist O.G. Encarnacion understands public control as the ability of citizens to regulate the freedom of action of the 
authorities and, therefore, to create the necessary system of legal position in the country, which would limit the overall permissiveness of the actions of authorities [25].

F. Schmitter expresses similar position, considering public control as one form of sanctioned influence of the citizen on the activity of public administration institutions, which are developed and realized exclusively within the framework of civil society [26, p. 53].

M. Howard's opinion being as an additional idea which considers public control as a norm of social relations, the realization of which should bear the nature of mutual consent and mutual coherence between the subjects of socio-political and state-administrative practice [27, p. 115-117].

Also, the concept of "public control" has not been ignored by both Russian and Ukrainian scientists. Some domestic scholars (and we assume there is a majority of them) are outlined to limit on mentioning this term in their scientific research text by identifying or correlating it with contiguous concepts [3]. Others, though dedicating some particular study to this issue, do not identify or specify it in any way. Nevertheless, there are Ukrainian researchers who study this type of control directly [28]. In their turn, having studied the working-outs of Russian scientists, it can be argued that they are overwhelmingly different in approach to the definition of the essence of this notion.

Having analyzed the most substantiated, as for us, scientific claims regarding public control, namely $\mathrm{N}$. Baranov and A. Bukhanevich, we conclude that the flaws of the definitions offered by scientists are numerous and obvious, which makes it impossible to speak about their general recognition. There are commonalities like inaccuracy, incorrectness, etc. And there are some of the terms, in particular, that N. Baranov brings concept "control" down exclusively to the concept of "adjustment", which does not correspond to the content of "control" meaning. In addition, the scientist, while talking about legislative and executive decisions, neglects their implementation [29]. A. Bukhanevich, in his turn, also interprets control rather narrowly, considering it as the supervision, which is different legal phenomenon. By the way, in terms of legal norms, he confuses the notions of "sanctioning" and "establishment", which regulate relations in the sphere of public control.

As for present day it is difficult to draw a "demarcation" line between public and civil controls, because the ideas lying within their foundation 
are partly overlaid on each other. We'd like to mention that the common features of these types of controls are that they are key factors in democratic processes that are directly linked to the formation of civil society being mechanisms for influencing upon power. The differences to be highlighted are as follows: 1) public control is an element in public policy, and civil control is in public; 2) public control is a condition of becoming a civil society, civil control is a condition of its development; 3 ) public control is a mechanism of influence on state power, while civil control - on public authority, which includes local self-government; 4) public control is not a prohibited form of activity of the public, with the purpose of ensuring the functioning of state power in accordance with the norms of the Constitution of Ukraine, laws of Ukraine, other normative legal acts and compliance them with its bodies, officials and positions as for the state discipline, and civil control is activities of the society in order to ensure the functioning of public power in accordance with the purpose stated and public goals. Therefore, public control is part of civil control.

\section{Public control and participation in state affairs management: the correlation of concepts}

Determining legal nature of public control there is another important issue which is related to it. This is the matter of the origin of the right for execution public control, for which there exist some rather ambiguous scientific claims.

Thus, the majority of domestic scientists associate public control with the right to participate in public affairs management $[26 ; 30 ; 36]$. Along with it the researchers do not consider the correlation of these concepts, their common and distinctive features, which does not allow to speak confidently about the interdependence of the legal nature of these legal phenomena.

In order to find out the degree of independence of the right to exercise and implement public control, we consider it necessary to examine the definitions of the right to participate in the management of public affairs and the concept of public control.

Speaking about the right to participate in public affairs management we have to mention that it was the subject of research of both domestic and foreign scientists. The work of American scholars deserves special attention, because today the USA is the most vivid example of a mature democracy. 
For example, K. Janda, J. Berry, and J. Goldman consider that participation in government affairs as the political participation, manifested by the actions of individual citizens, who in some way seek the way for influencing governmental power and state policy [30, with. 226].

Among Russian scientists special attention deserves the opinion of S.A. Shirobokov defining the right to participate in the management of public affairs through the concept of juridical institute, which is a stipulated procedure as it is (a set of established legal techniques, methods, instruments), through which a person has the opportunity to maximize his legitimate interest [31, p. 11]. However, there are also fundamentally opposite positions.

Russian researcher E.S. Selivanova interprets management of public affairs in more broad comprehension; considering it as political participation, the scientist understands it like some actions of individuals and groups of people aimed at influencing upon the bodies of state power and government. In addition, E. S. Selivanova emphasizes that it is the political participation that determines the effective practice of public control [32, p. 32].

The right to participate in the management of public affairs is also being developed by domestic scientists. In particular, A. V. Grabylnikov views this right as the legally enshrined opportunity for citizens to implement their power, in particular by participating in elections and referendums, having equal access to the state authority and service in local self-government bodies, while participating in the implementation processes of justice [33, p. 3-4].

At the same time, A. Drashkovych interprets the political participation of citizens from the standpoint of their participation in the process of formation, development, implementation, analysis and monitoring/control of state policy, considering it as a permanent interaction between the authorities and citizens. In addition, the researcher identifies the forms of this interaction, including public information, public consultations, public supervision, etc. [34].

From the point of view of democratic development in Ukraine, the opinion of O.O. Skibina, deserving special attention, who defines the participation of citizens in the management of state affairs as the activity of citizens in the sphere of implementing state power, which is conscious, free, active, public, voluntary, purposeful, legitimate, and also carried out to form and control the activity of state bodies for influencing the adoption, execution and implementation of state decisions [35, p. 3]. 
O.O. Chub, who considers participation in the management of state affairs as a constitutional right of citizens, provides for a similar position, which prerequisites the possibility of their active, public, voluntary, purposeful, legitimate activity in the sphere of exercising state power, the purpose of which is to form state authority bodies, along with control over their activity, influence on for their adoption, implementation of state decisions and control over their execution [36, p. 7].

With regard to the concept of public control, the Juridical Encyclopedia defines public control as a form of social control exercised by both citizens' associations and citizens themselves being active body of important form of democracy and the way of involving the population into governing the society and the state [37, p. 639].

Similar view is shared by the majority of scholars, considering public control as a form of direct democracy that involves public participation in public and state administration [38; 39; 40; 41; 42].

At the same time, I.M. Zharovska emphasizes that public account role is one of the functions of civil society, the essence of which is a public check of the activity of authorities, carried out by both citizens and their associations in order to contribute for compliance whether the goals reflect the authorities have voted for or whether they are moving towards achieving them. In addition, the focus of this control, according to the scientist's view is to adjust both the activities of these bodies and the goals themselves [43, p. 15].

Also, it would be worth paying attention on to I. Magnovsky's opinion, which defines public control in much broader sense. So, according to the scientist's view, public control is an instrument of the public that is effective in detecting, preventing, eliminating violations and protecting the rights and freedoms of citizens. At the same time, I. Magnovsky notes that the purpose of this control is to increase the key performance indicators of both public authorities and enterprises, institutions and organizations that directly provide services to citizens [44, p. 82].

Taking into account the analysis of the above, it can be noted that the historical and conceptual right to participate in the management of public affairs is a fundamental (constitutional) right. At present day taking a thorough look back at strengthening of the positions of the concept of democratic legal state and civil society, this right is becoming more complex, interpreted more broadly, that envisages certain forms of implementation and, accordingly, 
needs to be revised both for purely theoretical and practical purposes. Also, it would be necessary to mention that public control is a fundamental form of this right implementation, which allows to ensure the interaction of the state and civil society on the basis of equal partnership, mutual responsibility, etc.

\section{Conclusions}

The legal nature of public control is a value-normative basis for the interaction of the state and society, which stipulate original inception and development of the idea of limiting the activities of the state in order to satisfy public interest, which is provided, in particular, by the functioning of the feedback relations between the state power and the society.

In the modern sense and comprehension public control is considered to be the form of manifestation of the right to participate in public administration, which ensures the organization and the implementation of state power in the direction of fulfillment of tasks, functions and full powers assigned to it by the Law, as well as the achievement of the main goal being the insurance for human rights and freedoms including decent living conditions.

\section{References:}

1. Komissarova E.G. (2012). Formally logical aspects of the concept of "legal nature". Vestnik Permskogo universiteta, 2(16), 23-27. (in Russian)

2. Alekseev S.S. (1998). General Permissions and Prohibitions in Soviet Law. M.: Juridicheskaja literature. (in Russian)

3. Matveev I.V. (2002). Legal nature of invalid transactions. Candidate's thesis. M.: Gosudarstvennyj universitet upravlenija. (in Russian)

4. Dictionary of the Ukrainian language (1977). K.: Naukova dumka, 8. (in Ukrainian)

5. The most complete explanatory dictionary of the Ukrainian language (2012). URL: https://eslovnyk.com/

6. Kyseliov M. (2002). Nature: a philosophical encyclopedic dictionary. K.: Abrys. (in Ukrainian)

7. Skorokhodko E.F. (2006). A term in a scientific text. K.: Lohos. (in Ukrainian)

8. Pavlenko A.S. (2015). The legal nature of the Institute of Administrative Services. Legal regulation of public relations in the context of European integration: Proceedings of the Conference Title. Cherkasy: Cherkaskyi natsionalnyi universytet im. B. Khmelnytskoho. (in Ukrainian)

9. Kubrjakova E.S. (2012). In search of the essence of the language. Cognitive research. (Review of D. Lee. Cognitive Linguistics. An Introduction. New York: Oxford Univ. Press, 2002. 223 p.). M.: Znak. (in Russian)

10. Danylian O.H., Dzoban O.P., Maksymov S.I. (2009). Philosophy of Law. Kh.: Pravo. (in Ukrainian) 
11. Maksimov S.I. (2002). Legal reality: the experience of philosophical understanding. H.: Pravo. (in Russian)

12. Luk'janova E.G. (2011). Theory of Law and State. Introduction to natural law course. M.: Norma: INFRA-M. (in Russian)

13. Artemov V.M., Gunibskij M.Sh., Daleckij Ch.B., Demina L.A. (2016). Philosophy and law. M.: OOO "Prospekt". (in Russian)

14. Starchikova V.V. (2014). Public control in the constitutional state (legal and theoretical research). Candidate's dissertation. M.: Rossijskaja akademija gosudarstvennoj sluzhby pri Prezidente RF - FGOU VPO. (in Russian)

15. Jakushik V. (1993). Problems of typology of the constitutional state. Filosofskaja i sociologicheskaja mysl', 9-10, 177-195. (in Russian)

16. Solomin O.A. (2012). The concept of the constitutional state: a modern context. Naukovi zapysky NaUKMA, 134, 3-6. URL: http://nbuv.gov.ua/UJRN/ NaUKMAp 20121343 (in Ukrainian)

17. Amelchenko N.A. (2013). The values of the United Europe. K.: HO "Labaratoriia zakonodavchykh initsiatyv". URL: http://parlament.org.ua/ upload/docs/European_Values.pdf (in Ukrainian)

18. Radchenko O. $\overline{\mathrm{V}}$. (2009). The value system of society as a mechanism of democratic state formation. Kh.: Vyd-vo KharRI NADU "Mahistr". (in Ukrainian)

19. Kovler A.I. (1997). The crisis of democracy? Democracy at the turn of the 21st century. M.: Institut gosudarstva i prava RAN. (in Russian)

20. Vitvitskyi S.S. (2013). Institute of Civic Control in Ukraine: Concept, Essence, Development Trends. Naukovyi visnyk Dnipropetrovskoho derzhavnoho universytetu vnutrishnikh sprav, 1, 40-47. (in Ukrainian)

21. Pohorilko V.F. (2001). Problems of implementation of the Constitution of Ukraine: theory and practice. K.: A.S.K. (in Ukrainian)

22. Kravchuk V.M. (2016). Public authority control: clarification of the conceptual apparatus. Visegrad Journal on Human Rights, 1, 85-90. (in Ukrainian)

23. Poklad O.V. (2018) Public control over police activity. Candidate's dissertation. Z.: ZNU. (in Ukrainian)

24. Baranov S. (2007). Civilian control of power structures. Obozrevatel', 8, 51-55. (in Russian)

25. Encarnacion O.G. (2001). Tocqueville missionaries. Advocacy for civil society and support for democracy. URL: http://old.russ.ru/politics/meta/20010220_ toc.html (in Russian)

26. Schmitter F. (1996). Reflections about civil society and the consolidation of democracy. Polis, 5, 45-61. (in Russian)

27. Hovard Mark M. (2009). Weakness of civil society in post-communist Europe. M.: Aspekt Press. (in Russian)

28. Bukhanevych A.I. (2011). Public control over the activity of public authorities: a theoretical and methodological analysis. Candidate's dissertation. K.: Nats. akad. derzh. upr. pry Prezydentovi Ukrainy. (in Ukrainian)

29. Baranov N.A. (2007). Civil movements in Russia: problems of interaction. Russia and the modern world: problems of political developments: Proceedings of the 3 International Conference (pp. 377-386). M.: In-t biznesa i polit. (in Russian) 
30. Janda K., Berry J.M., Goldman J. (1989). The challenge of democracy: government in America. Boston: Houghton Mifflin Company.

31. Shirobokov S.A. (2011). Constitutional and legal aspects of citizen participation in the management of state affairs in the Russian Federation. Candidate's dissertation. Ekaterinburg. (in Russian)

32. Selivanova E.S. (2014). Institutionalization of public control in the field of public policy in modern Russia. Candidate's dissertation. Voronezh. (in Russian)

33. Grabylnikov A.V. (2006). The Constitutional Right of Ukrainian Citizens to Participate in Public Affairs: Problems of Theory and Practice. Candidate's dissertation. Kuiv. (in Ukrainian)

34. Drashkovych A. (2013). Political participation of citizens in the decisionmaking process. Politolohichni zapysky, 7. URL: http://nbuv.gov.ua/j-pdf/ Polzap_2013_7_28.pdf (in Ukrainian)

35. Skibina O.O. (2003). The concept of citizen participation in public affairs management: constitutional and legal aspects. Visnyk Kharkiv. nats. un-tu vnutr. sprav, 22. URL: http://nbuv.gov.ua/j-pdf/VKhnuvs_2003_22_62.pdf(in Ukrainian)

36. Chub O.O. (2004). Constitutional right of citizens of Ukraine to participate in the management of state affairs. Candidate's dissertation. Kharkiv. (in Ukrainian)

37. Shemshuchenko Yu.S. (1998). Legal Encyclopedia. K.: Ukrainska entsyklopediia, $1(\mathrm{~A}-\Gamma)$. (in Ukrainian)

38. Izha M. (2012). Public control in the system of public administration as an effective tool for examination of public-administrative decisions. Publichne upravlinnia: teoriia ta praktyka, 4(12), 74-79. (in Ukrainian)

39. Kushnir S.M. (2011). Legal remedies of public control in the mechanism of legal regulation. Candidate's dissertation. - Z. (in Ukrainian)

40. Melnyk A.F., Obolenskyi O.Yu., Vasina A.Yu., Hordiienko L.Yu. (2003). Governance. K.: Znannia-Pres. (in Ukrainian)

41. Rohatina L.P. (2011). Public control over the state: essence, mechanisms of implementation and prospects for development. Candidate's dissertation. (in Ukrainian)

42. Dzhafarova O.V. (2003). Legal basis of partnership between police and population. Extended abstract of Candidate's dissertation. Kharkiv. (in Ukrainian)

43. Zharovska I.M. (2012). Public control as an integral component in the concept of power relations of the modern state and civil society. Chasopys Kyivskoho universytetu prava, 3, 14-17. (in Ukrainian)

44. Magnovsky I. (2016). Legal understanding of public control at the present stage of state formation of Ukraine. Visnyk Natsionalnoho universytetu "Lvivska politekhnika", 855, 79-85. (in Ukrainian) 